\title{
Butterfly Pea (Clitoria Ternatea L.) Extract as Indicator of Acid- Base Titration
}

\author{
Bayu Wiyantoko*, Astuti \\ Diploma Program of Chemical Analysis \\ Faculty of Mathematics and Natural Sciences, Universitas Islam Indonesia, Yogyakarta \\ Jl. Kaliurang, Km 14,5, Sleman, Yogyakarta, 55584 \\ * corresponding author: bayuwiyantoko@uii.ac.id \\ DOI : 10.20885/ijca.vol3.iss1 .art4
}

\begin{tabular}{|c|c|}
\hline ARTIKEL INFO & ABSTRACT \\
\hline $\begin{array}{l}\text { Received : } 25 \text { January } 2019 \\
\text { Revised : 10 March } 2020 \\
\text { Published : } 15 \text { March } 2020 \\
\text { Kata kunci : Butterfly pea, } \\
\text { anthocyanins, acid, base, indicator, } \\
\text { titration }\end{array}$ & $\begin{array}{l}\text { An anthocyanin color pigment result from butterfly pea flower } \\
\text { maceration has been done. This study aims to determine the effect } \\
\text { of time variation in the maceration of anthocyanin butterfly pea } \\
\text { flower extract and the stability of butterfly pea flower extract as an } \\
\text { indicator of acid-base titration. Color pigment levels were } \\
\text { determined quantitatively with a UV-Visible spectrophotometer. } \\
\text { The anthocyanin levels obtained during the duration of maceration } \\
5 \text { days in a row resulted from } 4.3915 \% \text {, } 5.9869 \%, 7.3970 \% \text {, } \\
8.8995 \% \text {, and } 10.2864 \% \text {. While the anthocyanin levels using a } \\
\text { differential pH method were } 14.2775 \mathrm{mg} / \mathrm{L} \text { and } 14.9455 \mathrm{mg} / \mathrm{L} \text { with } \\
\% \text { RPD value was } 4.57 \% \text {. The results of the study stated that the } \\
\text { indicators of the butterfly pea flower crown extract can be a } \\
\text { substitute for the synthetic phenolphthalein indicator that has been } \\
\text { used. }\end{array}$ \\
\hline
\end{tabular}

\section{INTRODUCTION}

Anthocyanin color pigments from various plants are widely used in the food and medicine industry because they can make their colors attractive and safe for health. Anthocyanin color is strongly influenced by the structure of anthocyanin and the degree of acidity $(\mathrm{pH})$. Besides, anthocyanins tend to dissolve in polar solvents due to the presence of aromatic groups and glycosyl residues [1]. Anthocyanins are a type of secondary metabolite of the flavonoid family found in fruits and vegetables in large quantities. Anthocyanins are broadly divided into plant polyphenols in which flavonols, flavan-3-ol, flavones, flavanones, and flavonols are additional classes of flavonoids which differ in the oxidation of anthocyanins. Anthocyanins tend to be colorless in neutral $\mathrm{pH}$ areas, in solutions where the $\mathrm{pH}$ is very acidic $(\mathrm{pH}<3)$ gives the maximum red color, whereas in an alkaline solution $(\mathrm{pH} 10.5)$ the color pigment of the anthocyanin agent will change color to green if in an alkaline $\mathrm{pH}$ atmosphere [2].

One type of plant that contains anthocyanin is the butterfly pea flower [3]. Butterfly pea flower is a plant that has the Latin name Clitoria ternatea $L$ and Butterfly Pea in English, with anthocyanin as one of the active compounds giving a bluish-purple color to the flower crown that can function as an antibacterial as outlined in Table 1. This flower according to its name comes from Ternate region, Maluku which can grow in tropical regions such as Asia and its spread reaches South America, Africa, Brazil, North Pacific, and North America [1]. 


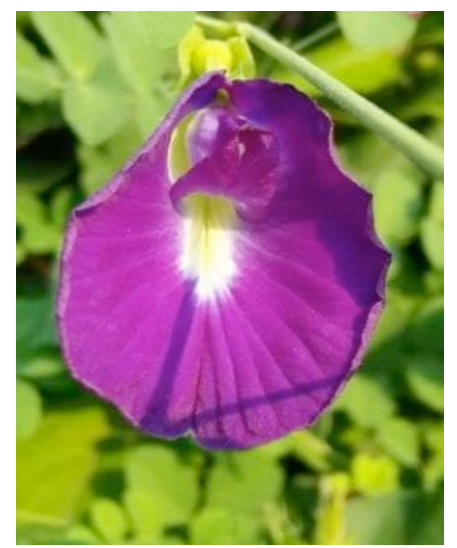

Figure 1. Butterfly Pea (Clitoria Ternatea L.)

TABEL 1. Contents of Active Compounds On Butterfly Pea Flowers [4]

\begin{tabular}{cc}
\hline Active Compounds & $\mathrm{nmol} / \mathrm{mg}$ flower \\
\hline Flavonoid & $20,07 \pm 0,55$ \\
Anthocyanin & $14,66 \pm 0,33$ \\
Flavonol glycoside & $12,71 \pm 0,46$ \\
Kaempferol glycoside & $5,40 \pm 0,23$ \\
Quercetin glycoside & $1,92 \pm 0,12$ \\
Myricetin glycoside & $0,04 \pm 0,01$ \\
\hline
\end{tabular}

Anthocyanin compounds give purple, blue and red colors to butterfly pea flowers where the anthocyanin phytochemical content has good stability so that it can be applied to natural dyes for foodstuffs and chemical testing indicators. To obtain anthocyanin compounds, extraction methods are needed, namely the process of separating components using certain solvents. There are 2 methods of anthocyanin extraction in testing namely cold and hot. Ways of extraction without heating include maceration and percolation, while methods that require heat include reflux, digestion, infusion, and soxhletation. Factors that can affect the extraction rate are the type of sample preparation, extraction time, a quantity of solvent, temperature of the solvent, and type of solvent.

The best solvent used for anthocyanin extraction in ethanol solvent [5]. The extraction process used is simpler maceration and is one of the most widely used methods and can avoid the destruction of thermolabile compounds found in butterfly pea flowers [1]. This research wants to study the use of solvents and effectiveness for the extraction of butterfly pea flowers (Clitoria ternatea L) and their application as an alternative indicator of acid-base. The structure of anthocyanin can be seen in Scheme 1.<smiles></smiles>

Scheme 1. Anthocyanin Structure

Organic compounds that can be used as indicators in acid-base titration have the characteristics of compounds that can provide color changes to the atmosphere of a $\mathrm{pH}$ solution. Color changes can occur due to the process of balancing the molecular and ionic shapes of an indicator compound. For example, phenolphthalein compounds are indicators of strong-weak acids and bases, undergoing a change in ion equilibrium followed by a change in color from colorless under acidic conditions to red under alkaline conditions. From the equilibrium reaction, it is known that the indicator compound is in the form of ions which can produce red color changes [6]. Color changes due to what happens because the compounds in phenol in the form of ions undergo delocalization to form quinoids. This 
research will study the process of anthocyanin extraction using the maceration method with ethanol solvent for five (5) days and the quality of the extract is tested as an alternative indicator of acid-base titration. Similar studies have been carried out for the titration indicator of standard $\mathrm{NaOH}$ solutions and standard solutions of $\mathrm{CH}_{3} \mathrm{COOH}$ using azo derivatives from eugenol which is 4-allyl-2-methoxy6-hydroxiazobenzene [6].

\section{METHOD}

\subsection{Tools and Materials}

The tools used in this study include a set of glassware, analytical balance (Ohaus), pH meter (Ohaus), hotplate, magnetic stirrer, a set of support devices, single beam UV-Visible Thermo scientific genesis 20 spectrophotometers.

The materials used are butterfly pea flowers, methanol (Merck), concentrated $\mathrm{HCl}$, ethanol solution $96 \%, \mathrm{HCl}$ solution $1 \%, \mathrm{NaOH}$ solution $10 \%, \mathrm{NaOH}$ solution $0.1 \mathrm{~N}$, billberry standard, $\mathrm{KCl}$ solution $0.0125 \mathrm{M}$, solution $\mathrm{CH}_{3} \mathrm{COONa} .3 \mathrm{H} 2 \mathrm{O} 0.2 \mathrm{M}$, phenolphthalein indicator, anhydrous oxalic acid, distilled water, filter paper, and aluminum foil.

\subsection{Making a standard solution of bilberry}

The standard solid of bilberry $20.20 \mathrm{mg}$ was dissolved with $60 \mathrm{~mL}$ of ethanol and then put into a $100 \mathrm{~mL}$ volumetric flask, ethanol was added to approach the etching boundary mark then shaken to homogenize the solution.

\subsection{Sample Preparation}

The cleaned butterfly pea flowers were put into a mortar. The fine butterfly pea flowers were weighed $25 \mathrm{~g}$ using a beaker glass, added a solvent in the ratio of 1: $4100 \mathrm{~mL} 96 \%$ ethanol and 100 $\mathrm{mL}$ distilled water then stirred using a magnetic stirrer at a temperature of $30{ }^{\circ} \mathrm{C}$. Samples were allowed to stand for 24 hours. Every day $20 \mathrm{~mL}$ extract was taken and then filtered to get the filtrate, the same thing was delivered for 5 days.

\subsection{Qualitative identification test}

The filtrate from the butterfly pea flower was taken for $7 \mathrm{~mL}, 2-3$ drops of $10 \% \mathrm{NaOH}$ were added, the color changes to green, then 2-3 concentrated $\mathrm{HCl}$ was added until the color turns red.

\subsection{Determination of anthocyanin levels in butterfly pea flower}

A $12 \mathrm{~mL}$ extract solution was added with methanol containing $1 \% \mathrm{HCl}$ to a $100 \mathrm{~mL}$ volumetric flask. The absorbance of anthocyanin extract was measured at a maximum wavelength of $528 \mathrm{~nm}$ then the absorbance was recorded at that wavelength range. Anthocyanin levels were determined using equation 1.

Anthocyanin level $=\frac{\text { Sample absorbance }}{\text { Standard absorbance }} \times$ concentration of billberry standar $\mathrm{x}$ DF $\mathrm{x}$ Extract volume $\mathrm{x}$ 0,418

For testing of anthocyanin level using a differential $\mathrm{pH}$, for $1 \mathrm{~mL}$ of butterfly pea flower extract, added $9 \mathrm{~mL}$ of $\mathrm{KCl}$ solution $\mathrm{pH} 1$, put into $10 \mathrm{~mL}$ volumetric flask and then homogenized. The same was done for the $\mathrm{CH}_{3} \mathrm{COONa} .3 \mathrm{H}_{2} \mathrm{O}$ solution $\mathrm{pH}$ of 4.5 . The absorbance of anthocyanin extract was measured at a maximum wavelength of $500 \mathrm{~nm}$ and $700 \mathrm{~nm}$ then recorded at that wavelength range. The test was carried out two replicates where the anthocyanin level using the differential $\mathrm{pH}$ method is determined using equation 2 .

$$
\begin{aligned}
& \mathrm{A}=\left(\mathrm{A}_{520}-\mathrm{A}_{700}\right) \mathrm{pH}_{1}-\left(\mathrm{A}_{520}-\mathrm{A}_{700}\right) \mathrm{pH}_{4.5} \\
& \text { Anthocyanin level }=\frac{\mathrm{AxMWxDFx1000}}{\varepsilon \times 1}
\end{aligned}
$$

Keterangan: A for absorbance

MW for the molecular weight of cyaniding-3-glucoside $(449,2 \mathrm{~g} / \mathrm{mol})$

DF for the dilution factor

E for molar absorptivity of cyaniding-3-glucoside $(26900 \mathrm{~L} / \mathrm{mol})$

1 for cuvette wide $(\mathrm{cm})$ 


\section{RESULT}

\subsection{Results of identification of color pigments}

This research was carried out with a maceration time of 5 days with a solvent ratio of 1: 4 and a flower weight of $25 \mathrm{~g}$ flower at room temperature with a wavelength of $528 \mathrm{~nm}$. The results of tests in the form of qualitative identification are presented in Table 2.

TABLE II. Qualitative Test Results

\begin{tabular}{cccc}
\hline Maceration time & Basic color & After adding NaOH 10\% & $\begin{array}{c}\text { After adding } \mathrm{HCl} \\
\text { glacial }\end{array}$ \\
\hline Day 1 & Purple & Green & Red \\
Day 2 & Purple & Green & Red \\
Day 3 & Purple & Green & Red \\
Day 4 & Purple & Green & Red \\
Day 5 & Purple & Green & Red \\
\hline
\end{tabular}

To identify anthocyanin, the extract obtained from maceration is filtered and then put into a test tube as much as $1 \mathrm{~mL}$. The color of the anthocyanin compound is purple with a $\mathrm{pH}$ of 5 , then the extract is dropped with $10 \% \mathrm{NaOH}$ by 2 drops, the anthocyanin compound changes to green at $\mathrm{pH}$ 10 , after that the extract is dropped later with concentrated $\mathrm{HCl} 2$ drops then the anthocyanin compound turns red with a $\mathrm{pH}$ of 3.5 The butterfly pea flower has a blue base color where the blue color appears due to the color degradation process of anthocyanin which is in the form of a red cavity flavilium to a blue quinoidal base. In a liquid medium, anthocyanin undergoes structural changes because the instability of anthocyanin is influenced by $\mathrm{pH}$. Anthocyanin compounds in very acidic conditions $(\mathrm{pH}<2)$ is dominated by flavilium cations that are red, whereas in conditions of weak acidity, neutral, or alkaline the carbinol (colorless) and quinoidal base (blue) dominate the cavity flavilium so that the color fades (colorless) and changes from red to blue. Increasing $\mathrm{pH}$ value makes carbinol and chalcone base compounds more and more formed which causes colorless [7]. Changes in color at different $\mathrm{pH}$ values indicate that flower extracts of butterfly pea have the potential to be used as an alternative indicator of acid-base titration.

The event of anthocyanin color changes at different $\mathrm{pHs}$ due to the intermolecular copigmentation process between anthocyanin color pigments and copigment compounds characterized by a shift between bathochromic and hyperchromic. Batochromic shift (redshift or bathochromic effect) is a shift at the peak of absorption in the direction of a larger wavelength. This happened because of the substitution of the glycone or aglycone group or the effect of the solvent. Hyperchromic effects are effects that can be caused by functional groups, causing an increase in the value of maximum absorption intensity. The addition of hydroxyl groups results in a shift toward green (pelargonidin $\rightarrow$ cyanidin $\rightarrow$ delphinidin), where glycoside formation and methylation produce a shift toward red (pelargonidin $\rightarrow$ pelargonidin-3-glucoside; cyanidin $\rightarrow$ peonidin) [7]. 


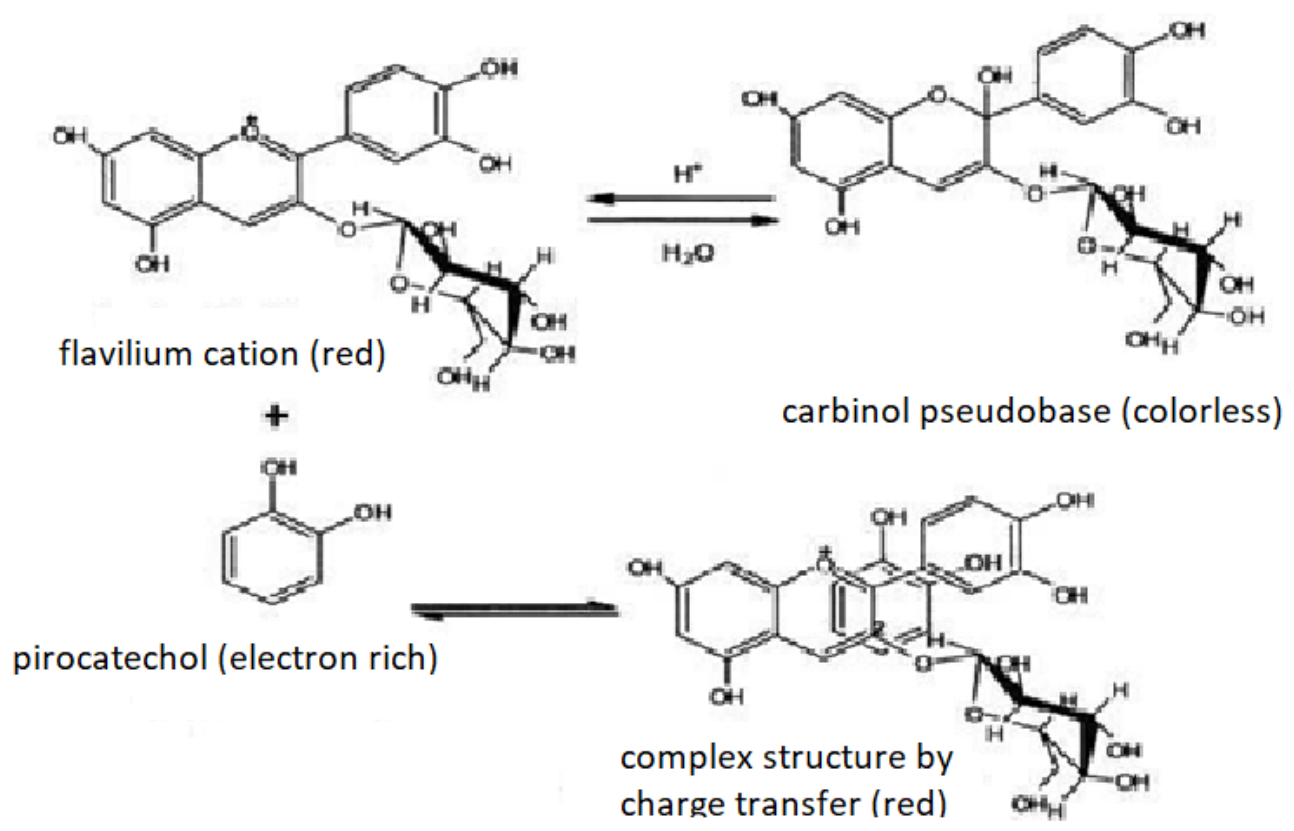

Figure 2. Transfer of color pigment anthocyanin complex with catechol [8]

\subsection{Result of Anthocyanin Concentration}

The study of anthocyanin levels was carried out with maceration time variables, namely 1, 2, 3, 4 and 5 days and the weight of $25 \mathrm{~g}$ flowers at $30^{\circ} \mathrm{C}$ and a wavelength of $528 \mathrm{~nm}$. The results of tests in the form of anthocyanin levels are presented in Table 3.

TABLE III. Results of Anthocyanin Levels

\begin{tabular}{cccc}
\hline No & Maceration time & Dilution factor & Anthocyanin Concentration $(\mathrm{mg} / \mathrm{L})$ \\
\hline 1 & Day 1 & 5 kali & 4,391 \\
2 & Day 2 & 5 kali & 5,987 \\
3 & Day 3 & 5 kali & 7,397 \\
4 & Day 4 & 5 kali & 8,899 \\
5 & Day 5 & 5 kali & 10,286 \\
\hline
\end{tabular}

The anthocyanin extract obtained from maceration was then diluted again with $1 \% \mathrm{HCl}$ in methanol as much as $500 \mathrm{~mL}$, after which it was inserted into a UV-Vis spectrophotometer. The first blank that added $1 \% \mathrm{HCl}$ solvent in methanol obtained 0,000 absorbances. The next blank is a billbery extract that has known concentration. The absorbance yield of billberry extract was 0.526 . The diluted sample was entered into a UV-Vis spectrophotometer for the results compared to a standard comparison of billberry extract. Anthocyanin levels were calculated using equation 1 , while the relationship between anthocyanin levels and maceration time is shown in Figure 3.

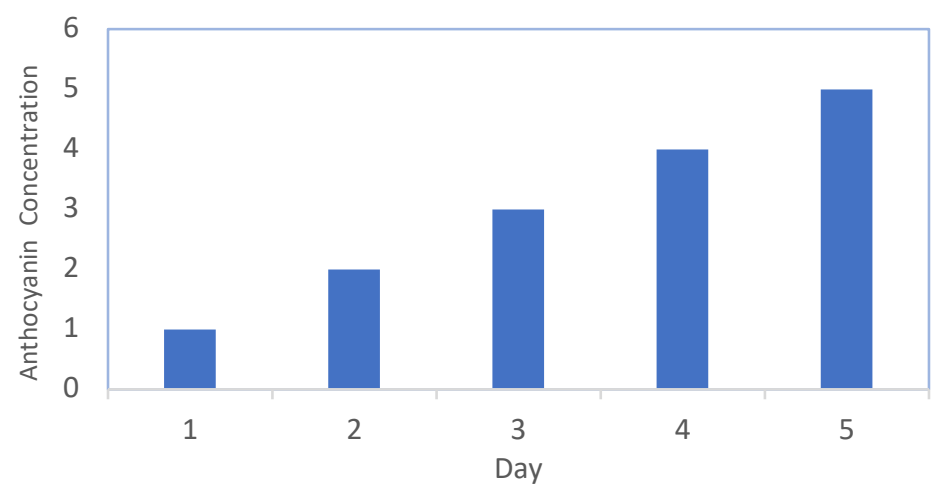

Figure 3. Effect of maceration time on the color levels of butterfly pea flower pigments 
The results of the stem diagram of the sample levels of the butterfly pea flower extract show that the color pigment levels obtained are increased where $\mathrm{y}$ is the color pigment level $(\mathrm{mg} / \mathrm{L})$ and $\mathrm{x}$ is the maceration time (day). From the results of the study note that the longer the maceration time used, the greater the level of color pigment obtained is also proportional to the concentration of the anthocyanin compound. The higher concentration of anthocyanin pigments causes increased chorma, which can be heard by higher extract levels [9]. In addition to the duration of time, the type of solvent extraction process affects the levels of color pigments because anthocyanins dissolve in polar solvents such as ethanol which are easily absorbed by cell membranes so that membrane breakdown occurs on the surface of tissue particles in flower petals [5].

In this study, the extraction process depends entirely on the ethanol solvent and the duration of time alone because there is no addition of acid solutions and the use of high temperatures (heating). As is known, acidic solution and heating will further optimize the yield of anthocyanin but the potential for damage (degradation) of anthocyanin compounds also arises due to heating through the hydrolysis of glycosidic bonds to produce aglycones and the opening of the aglycone ring to form carcinol groups and colorless chalcones [10].

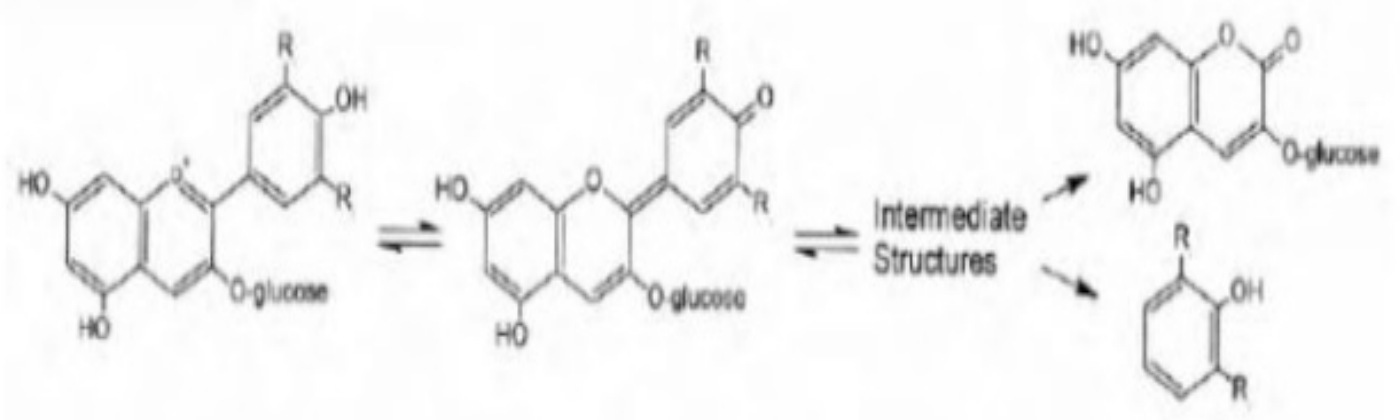

Figure 4. Mechanism of anthocyanin degradation at temperatures over $70^{\circ} \mathrm{C}$

\subsection{Total Concentration of Anthocyanin using pH Differential}

Color pigments that have been dissolved in $\mathrm{pH} 1$ and $\mathrm{pH} 4.5$ are measured for their absorbance with wavelengths of $520 \mathrm{~nm}$ and $700 \mathrm{~nm}$. The wavelength of $520 \mathrm{~nm}$ is the maximum wavelength to determine cyaniding-3-glucoside while the wavelength of $700 \mathrm{~nm}$ is to correct deposits or impurities that are still present in the sample. It is known that anthocyanin compounds have 4-5 different structures in aqueous solutions with different $\mathrm{pH}$ as outlined in Table 4.

TABLE IV. Form of anthocyanin molecules at various $\mathrm{pH}$ values

\begin{tabular}{ll}
\hline $\mathrm{pH}$ value & Molecular Form \\
\hline $1-3$ & Red flavylium cation \\
$4-5$ & Colorless carbinol pseudo base \\
$6-7$ & Purple quinonoidal base \\
$7-8$ & Blue anionic quinonoidal base \\
$8-9$ & Pale yellow chalcone \\
\hline
\end{tabular}

For anthocyanin compound extracts of butterfly pea flower which were dissolved at $\mathrm{pH} 1$ and $\mathrm{pH} 4.5$ showed a typical spectrum pattern shown in Figure 5 as reported by [11] who conducted a study of color stability and spectrum characteristics. At $\mathrm{pH} 4$, the butterfly pea flower extract shows two wave peaks $\left(\lambda_{\text {peak }}\right)$ representing quinonoidal base and anionic quinonoidal base while one supporting wave peak $\left(\lambda_{\text {shoulder }}\right)$ represents the species flavylium cation. 

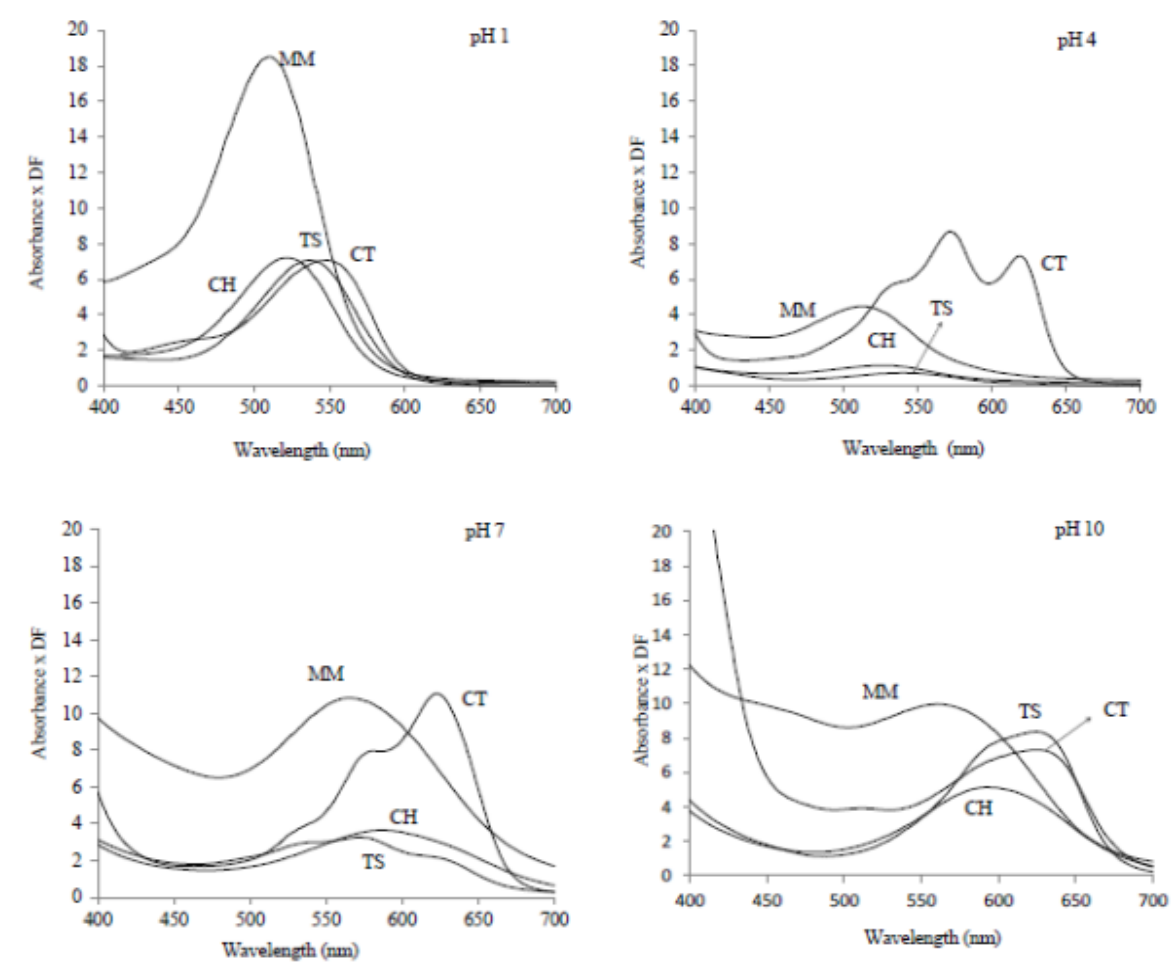

Figure 5. UV-Visible spectrum for Melastomataceae and Clitoria ternatea L extracts [11]

If the sample is really clear then the absorbance at $700 \mathrm{~nm}$ is 0 [12]. The absorbance of anthocyanin that has been dissolved at $\mathrm{pH} 1$ and 4.5 can be seen in Tables 5 and 6 .

TABLE V. The absorbance results using a differential $\mathrm{pH}$ of 1.0

\begin{tabular}{ccccc}
\hline \multirow{2}{*}{ Wavelength $(\mathrm{nm})$} & \multicolumn{3}{c}{ Absorbance } & \multirow{2}{*}{ Average } \\
\cline { 2 - 4 } & $\mathrm{A}_{1}$ & $\mathrm{~A}_{2}$ & $\mathrm{~A}_{3}$ & \\
\hline \multirow{2}{*}{720} & 0,095 & 0,0945 & 0,095 & 0,0948 \\
& 0,095 & 0,095 & 0,094 & 0,0946 \\
& 0,005 & 0,006 & 0,005 & 0,0057 \\
& 0,006 & 0,005 & 0,005 & 0,0057 \\
\hline
\end{tabular}

TABLE VI. The absorbance results using a differential $\mathrm{pH}$ of 4,5

\begin{tabular}{ccccc}
\hline \multirow{2}{*}{ Wavelength $(\mathrm{nm})$} & \multicolumn{3}{c}{ Absorbance } & Average \\
\cline { 2 - 4 } & $\mathrm{A}_{1}$ & $\mathrm{~A}_{2}$ & $\mathrm{~A}_{3}$ & \\
\hline \multirow{2}{*}{520} & 0,08 & 0,08 & 0,08 & 0,080 \\
& 0,079 & 0,079 & 0,079 & 0,079 \\
& 0,008 & 0,008 & 0,008 & 0,008 \\
& 0,008 & 0,00 & 0,008 & 0,008 \\
\hline
\end{tabular}

The results of the study can be calculated using equation 2 . Total anthocyanin level in the first butterfly pea flower is $14.2775 \mathrm{mg} / \mathrm{L}$, while the second anthocyanin level is $14.9455 \mathrm{mg} / \mathrm{L}$ with a $\%$ RPD value of $4.57 \%$, the value of $\%$ RPD produced is good because it is less than the specified threshold of $>5 \%$. The results show that the higher the absorbance obtained, the more anthocyanin levels. Determination of anthocyanin concentration by the $\mathrm{pH}$ differential method because at $\mathrm{pH} 1.0$ anthocyanin forms a colored oxonium (cation flavilium) compound and at $\mathrm{pH} 4.5$ it forms a colorless carbinol/hemiketal [13].

Measurement of total anthocyanin levels using this method is a calculation through visible light at different pHs. Research on anthocyanin content which is mostly found in plants is cyaniding-3- 
glucoside with molar absorptivity $(\varepsilon)$ of 26,900 . Generally, cyanidin-3-glucoside is used as a reference compound of anthocyanin [14].

The indicator results of the butterfly pea flower extract show a change in color ie in a red acid solution and a green base [15]. Anthocyanin in its structure contains cation flavilium, color changes can occur due to changes in the shape of the structure caused by the influence of $\mathrm{pH}$. The results of the analysis of butterfly pea flower extracts are the color of the solution in $\mathrm{pH}$ is bluish-green where the shape changes in the color pigment structure due to the influence of the $\mathrm{pH}$ value. The anthocyanin structure in Scheme 1, under red acidic conditions, if the $\mathrm{pH}$ is increased $(\mathrm{pH}<4)$ a colorless carbinol base (3) is formed and further as shown in Figure 6.

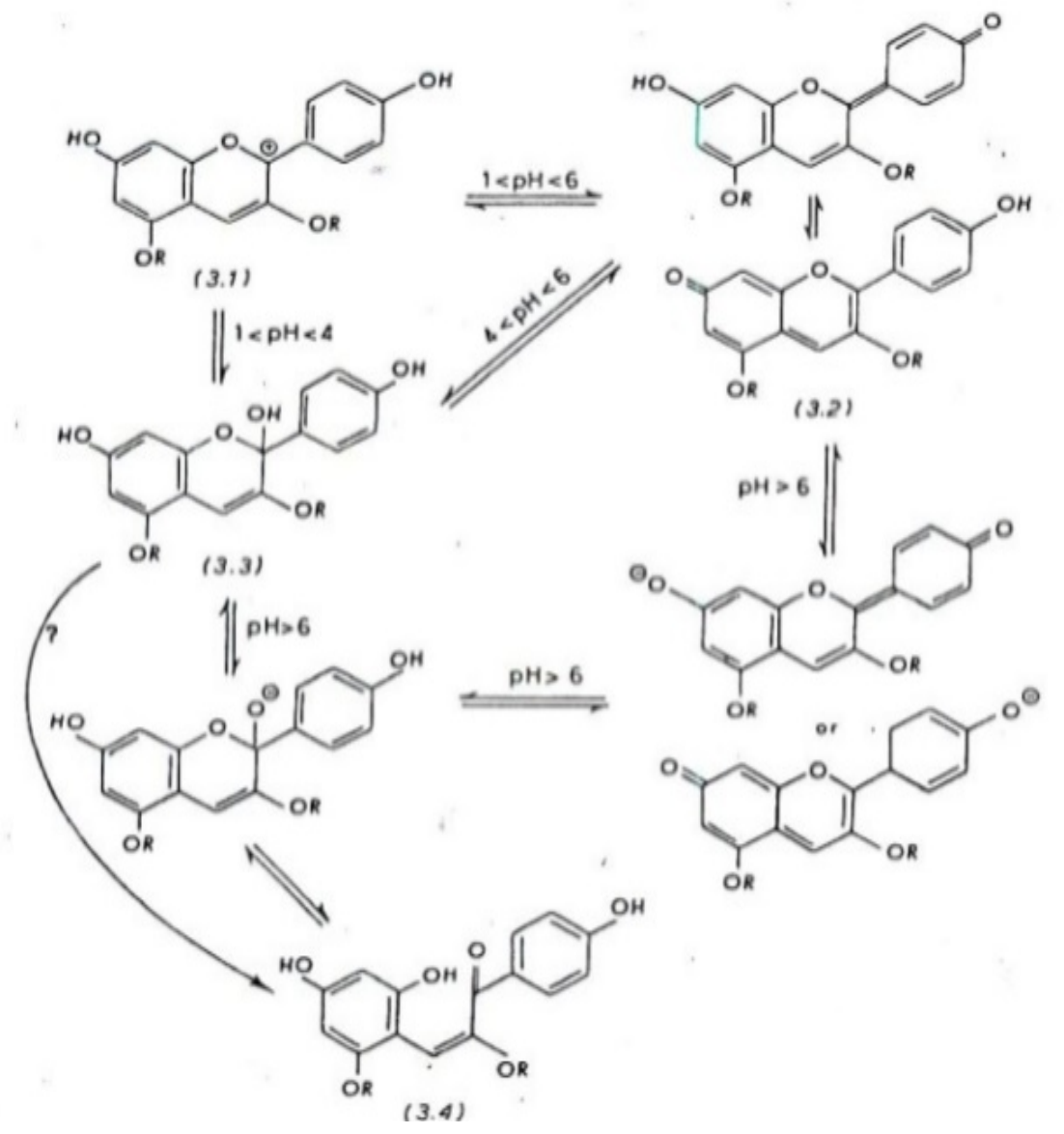

Figure 6 . The equilibrium form of the flavilium cation in anthocyanins in various $\mathrm{pH}$ ranges $([16][17])$

\subsection{Control Chart of Butterfly Pea Flower Extract as An Indicator of Titration}

Butterfly Pea flower extract obtained from maceration for 5 days will be used as an indicator in the simulation of acid-base titration. In this test, the performance indicator of butterfly pea flower extract will be assessed for its performance with the phenolphthalein indicator as a dick or reference. The results of titration testing are shown in Table 7.

TABLE VI. The titration results using the phenolphthalein indicator and the butterfly pea flower extract indicator

\begin{tabular}{ccc}
\hline \multirow{2}{*}{ Day- } & \multicolumn{2}{c}{ The volume of $\mathrm{NaOH}(\mathrm{mL})$} \\
& Phenolphthalein & Butterfly Pea \\
\hline 1 & 8,47 & 8,60 \\
2 & 8,70 & 9,80 \\
3 & 8,85 & 8,70 \\
4 & 8,60 & 9,70 \\
5 & 8,85 & 8.85 \\
6 & 8,53 & 9.85 \\
\hline
\end{tabular}




\section{Average} 8,66 9,25

The volume of $\mathrm{NaOH}$ produced from acid-base titration using the phenolphthalein indicator and the butterfly pea flower extract indicator has an average difference of $0.59 \mathrm{~mL}$ so that the butterfly pea flower extract indicator can be used as an alternative indicator of phenolphthalein. To find out the stability of butterfly pea flower extract as an indicator, a control chart is needed as shown in Figures 7 and 8 . Acid-base titration was used in this study because anthocyanin compounds in the flower had a change in color at a certain $\mathrm{pH}$ value which also corresponds to the $\mathrm{pH}$ range of the phenolphthalein indicator.

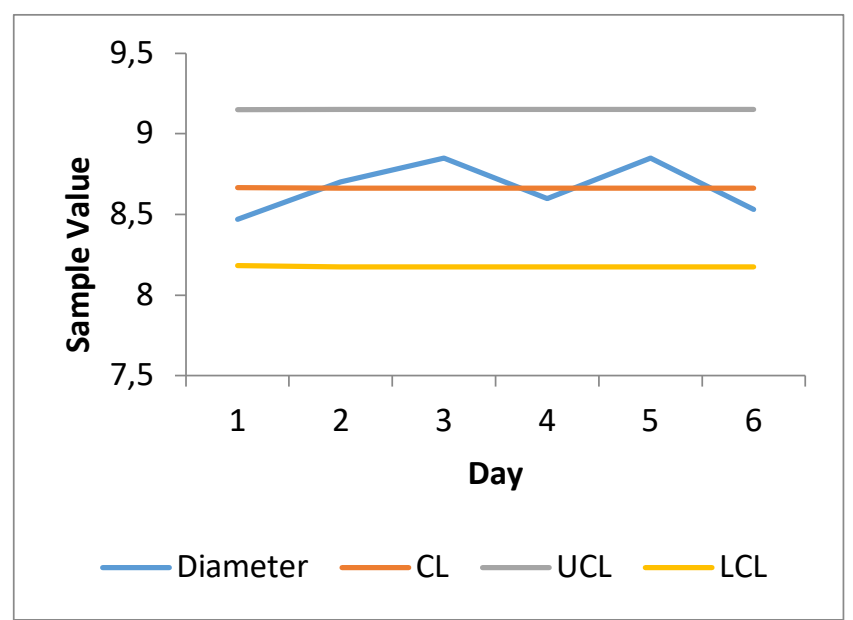

Figure 7. The control chart of phenolphthalein indicator control

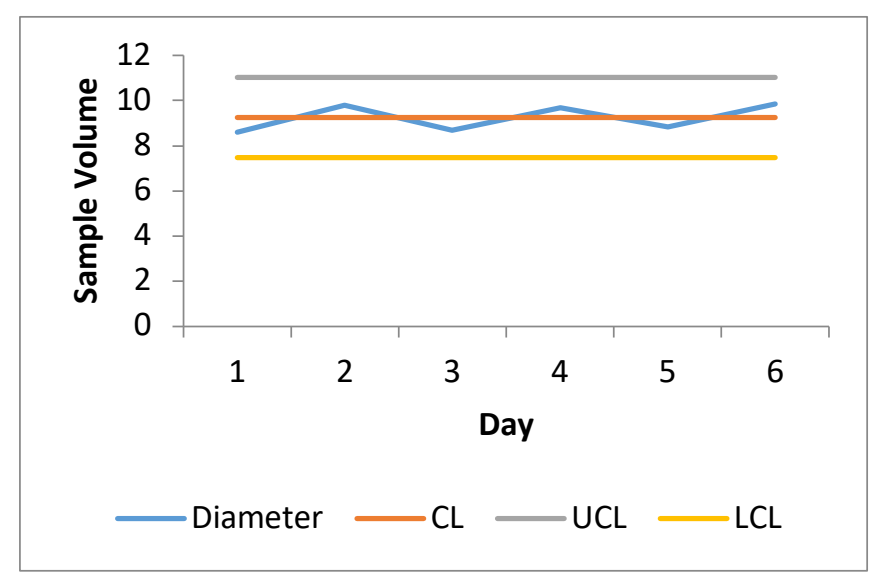

Figure 8. Control Chart of Butterfly pea Flower Extract Indicators

The phenolphthalein indicator is an acid-base titration indicator which has a $\mathrm{pH}$ range of 8.09.6 used as a comparison indicator. The graph shows that for six (6) days, the phenolphthalein indicator and the banana flower extract are still between the Upper Control Limit (UCL) and Lower Control Limit (LCL), meaning that both indicators are at the control limit or stable test results. These results indicate that the phenolphthalein indicator and butterfly pea flower extract can be used for 6 days even though there is a difference in the volume of $\mathrm{NaOH}$ needed at titration but is not significant. The volume of $\mathrm{NaOH}$ produced by the butterfly pea flower extract indicator is greater than the phenolphthalein indicator due to differences in $\mathrm{pH}$ values. The control chart itself is used to see the consistency of the analyst, the stability of the equipment, the difficulty level of the method used, and to know the durability of the butterfly pea flower extract as a test sample.

\section{CONCLUSION}

Color pigments can be obtained by extracting butterfly pea flowers using a maceration method 
that can produce concentrated purple extracts. Anthocyanin from butterfly pea flowers can be used as an indicator of the acid-base because the color pigment changes its color when it drops acid or base and natural dyes. When the maceration was obtained anthocyanin levels for 5 consecutive days namely $4.3915 \%, 5.9869 \%, 7.3970 \%, 8.8995 \%$, and $10.2864 \%$.

The total concentration of color pigments from butterfly pea flowers can be determined by the $\mathrm{pH}$ differential method by spectrophotometry. The results showed a total concentration of 14.2775 $\mathrm{mg} / \mathrm{L}$ and $14.9455 \mathrm{mg} / \mathrm{L}$ with a\% RPD value of $4.57 \%$. Color changes occur in butterfly pea flower extracts due to the presence of anthocyanin compounds, which in their structure contain cations of flavilium to form anhydrobase due to changes in $\mathrm{pH}$. Butterfly pea flower extract indicator has similarities with phenolphthalein, so it can be a substitute for acid-base titration indicators.

\section{Acknowledgment}

Thank you to the applied chemistry laboratory which has provided facilities to work on this project and to the Diploma Program of Chemical Analysis that has held the Indonesian Vocational National Seminar, so that the means for the publication of the results of this research.

\section{Daftar Pustaka}

[1] L. Angriani,"Potensi ekstrak bunga telang (Clitoria ternatea) sebagai pewarna alami lokal pada berbagai industri pangan," Canrea J., vol. 2, no. 2, pp. 32-37, 2019

[2] K. Torskangerpoll and Ø. M. Andersen,"Colour stability of anthocyanins in aqueous solutions at various pH values," Food Chem., vol. 89, no. 3, pp. 427-440, 2005

[3] E. Mastuti, G. Fristianingrum, and Y. Andika,"Ekstraksi Dan Uji Kestabilan Warna Pigmen Antosianin Dari Bunga Telang (Clitoria Ternatea L.) Sebagai Bahan Pewarna Makanan," Simp. Nas. RAPI XII, pp. 44-51, 2013

[4] B. Anthika, S. P. Kusumocahyo, and H. Sutanto,"Ultrasonic Approach in Clitoria ternatea (Butterfly Pea) Extraction in Water and Extract Sterilization by Ultrafiltration for Eye Drop Active Ingredient," Procedia Chem., vol. 16, no. 6, pp. 237-244, 2015

[5] R. Moulana, Juanda, S. Rohaya, and R. Rosika,"Efektivitas Penggunaan Jenis Pelarut dan Asam dalam Proses Ekstraksi Pigmen Antosianin Kelopak Bunga Rosella (Hibiscus sabdariffa L)," J. Teknol. dan Ind. Pertan. Indones., vol. 4, no. 3, pp. 20-25, 2012

6] B. Purwono and C. Mahardiani,"Synthesis of Azo Compounds Derivative From Eugenol and Its Application As a Titration Indicator," Indones. J. Chem., vol. 9, no. 1, pp. 95-98, 2010

[7] T. Sari, P., Agustina, F., Komar, M., Unus, M. F., \& Lindriati,“Ekstraksi dan Stabilitas Antosianin dari Kulit Buah Duwet," Jurnal Teknol. dan Industri Pangan, vol. XVI, no. 2. pp. 142-150, 2005

[8] A. Castañeda-Ovando, M. de L. Pacheco-Hernández, M. E. Páez-Hernández, J. A. Rodríguez, and C. A. Galán-Vidal,"Chemical studies of anthocyanins: A review," Food Chem., vol. 113, no. 4, pp. 859-871, 2009

[9] J. F. Gonnet,"Colour effects of co-pigmentation of anthocyanins revisited - 1. A colorimetric definition using the CIELAB scale," Food Chem., vol. 63, no. 3, pp. 409-415, 1998

[10] A. Zussiva, K. L. Bertha, and C. S. Budiyati,"Ekstraksi dan Analisis Zat Warna Biru (Anthosianin Anthosianin) dari Bunga Telang (Clitoria Ternatea) Sebagai Pewarna Alami," J. Teknol. Kim. dan Ind., vol. 1 , no. 1 , pp. 356-365, 2012

[11] A. M. Marpaung, N. Andarwulan, P. Hariyadi, and D. N. Faridah,"Spectral Characteristics and Color Stability of Melastomataceae and Clitoria ternatea L. Extracts, 17th Food Innovation Asia Conference 2015 (FIAC 2015) Innovative ASEAN Food Research towards the World, Bangkok, Thailand, 18-19 June 2015.

[12]W. Supiyanti, D. E. Wulansari, and L. Kusmita,"Uji Aktivitas Antioksidan Dan Penentuan Kandungan Antosianin Total Kulit Buah Manggis (Garcinia mangostana L), Maj. Obat Tradis., vol. 15, no. 152, pp. 64-70, 2010

[13] M. Mónica Giusti and R. E. Wrolstad,“Characterization and Measurement of Anthocyanins by UV-visible 
Spectroscopy," Handb. Food Anal. Chem., vol. 2-2, pp. 19-31., 2005

[14]E. N. Bridgers, M. S. Chinn, and V. Den Truong,"Extraction of anthocyanins from industrial purplefleshed sweetpotatoes and enzymatic hydrolysis of residues for fermentable sugars," Ind. Crops Prod., vol. 32, no. 3, pp. 613-620, 2010

[15] V. Bhagat, R. Patil, P. Channekar, S. Shetty, and A. Akarte,"Herbal indicators as a substituent to synthetic indicators," Int. J. Green Pharm., vol. 2, no. 3, p. 162, 2008

[16]R. Brouillard and B. Delaporte,"Chemistry of Anthocyanin Pigments. 2.1 Kinetic and Thermodynamic Study of Proton Transfer, Hydration, and Tautomeric Reactions of Malvidin 3-Glucoside," J. Am. Chem. Soc., vol. 99, no. 26, pp. 8461-8468, 1977

[17]R. Brouillard, G. A. Iacobucci, and J. G. Sweeny,"Chemistry of Anthocyanin Pigments. 9. UV-Visible Spectrophotometric Determination of the Acidity Constants of Apigeninidin and Three Related 3Deoxyflavylium Salts," J. Am. Chem. Soc., vol. 104, no. 26, pp. 7585-7590, 1982

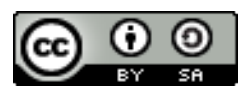

Jurnal IJCA is licensed under aÂ Creative Commons Attribution ShareAlike 4.0 